\title{
How to Make a Revolution: Revolutionary Rhetoric in the European Humanities around 1800
}

\author{
Floris Solleveld, Radboud University Nijmegen
}

\begin{abstract}
A BSTRACT
Works of scholarship in the late eighteenth and early nineteenth centuries abounded in programmatic proclamations of new disciplines and critical dismissal of all predecessors. In this article I make an inventory of different kinds of such explicit and implicit revolutionary rhetoric in the study of language and history around 1800. Analyzing these proclamations as performative speech acts, I identify various criteria according to which such speech acts can be said to fail or succeed. Together, they raise the question to what extent the notion of a "scientific revolution" is applicable at all to developments the humanities, roughly analogous to the "second scientific revolution" that some authors have identified in the same period. Although none of this rhetoric explicitly proclaims a scientific revolution in the humanities, the accumulation of it serves to show that the notion of a "scientific revolution" does not conflict with actor's categories and cannot be written off as anachronistic.
\end{abstract}

n 1785, Göttingen professor of philosophy Christoph Meiners presented the outline of a "Geschichte der Menschheit." By Geschichte he meant a natural history of mankind, a kind of comparative anthropology that took into account such factors as climate, race, diet, commerce, and customs. He started his sketch with a weary complaint:

Nothing is more common than to re-arrange single parts of known sciences according to one's own particular plan, and to present this newly arranged system of old knowledge as a new science, with the proud gesture of an inventor. However, if the author does not want merely to erect a short-lasting monu-

This article was written during a stay as guest researcher at the Max Planck Institute for the History of Science, Berlin. I would like to thank Kevin Ku-Ming Chang and Robert-Jan Wille as well as two reviewers for comments on earlier versions.

History of Humanities, Volume 1, Number 2. http://dx.doi.org/10.1086/687920

(C) 2016 by The University of Chicago. All rights reserved. $2379-3163 / 2016 / 0102-0005 \$ 10.00$ 
ment to his own vanity, or to cause unnecessary confusion, then he should never announce a new science, unless he delivers things that have either not been studied properly before, or not at all. ${ }^{1}$

This, ironically, pretty much sums up the critique that his own work incited. Georg Forster, who had traveled through the Pacific on board Cook's second expedition, wrote a crushing review in which he pointed out that Meiners's Grundriß was not based on observation but rather on a selective and sloppy reading of travel accounts, guided by European complacence. In particular, Forster took issue with Meiners's central tenet that one should not distinguish between races on the basis of color, which was arbitrary because color depended on climate - but rather on the basis of facial form, between "Caucasian" and "Mongolian," or "beautiful" and "ugly" races.

A decade before, Forster had presented his own Voyage round the World as "a philosophical history of the voyage, free from prejudice and vulgar error, where human nature should be represented without any adherence to fallacious systems, and upon the principles of general philanthropy; in short, an account written upon a plan such as the learned world had not seen previously executed." ${ }^{3}$ Meiners, in Forster's review, becomes the negative image of that. It must be said to Meiners's credit that he subsequently revised his race theory; ${ }^{4}$ moreover, he inspired his colleague Blumenbach to do the same with less overt prejudice and with a data set of hundreds of skulls. All the same, Meiners's proclamation of a new "Geschichte der Menschheit" failed, at least if measured by his own ambition to start a new field of science by that name. His main contribution to the history of ideas is that he invented the term Caucasian.

Two things are particularly relevant about the rhetoric of his Grundriß. First, there is the self-conscious ambition to found a new discipline. And second, there is his awareness that this has been done before.

For Meiners, apparently, proclaiming a new science was a valid rhetorical move, one that could succeed or fail, but that needs not to be taken at face value. Moreover, his proposal does not fit in modern categories of science, or even Wissenschaft: as a professor of Weltweisheit, he proposes a philosophical history that crosses from cultural history to histoire naturelle. His weary complaint comes before the disciplinary shifts that have traditionally been regarded as the formation of the modern humanities.

1. Christoph Meiners, Grundriß der Geschichte der Menschheit (Göttingen: Röwer, 1785), 2-3. Translations are my own unless otherwise indicated.

2. Georg Forster, review of Christoph Meiners, Grundriß der Geschichte der Menschheit, Allgemeine Litteratur-Zeitung, May 4-6, 1789.

3. Georg Forster, A Voyage round the World (London: White et al., 1777), iv.

4. See Michael Carhart, "Polynesia and Polygenism: The Scientific Uses of Travel Literature in the Early 19th Century," History of the Human Sciences 22, no. 2 (2009): 58-86. 
This article offers an inventory of such rhetoric in the course of these disciplinary shifts. It treats proclamations of "new sciences" and new approaches as performative speech acts, that is, as attempts to enact or institute something through words. But what exactly did they bring about? In an earlier article, I have argued that most researchers on the history of scholarship tacitly assume that something like a "scientific revolution" took place in the humanities around 1800 , without calling it so. ${ }^{5}$ My aim here is not to prove that assumption true but rather to investigate to what extent historical agents had similar ideas. That in itself puts the history of scholarship in a new light.

\section{THE SECOND SCIENTIFIC REVOLUTION AND THE HUMANITIES}

When does one speak of a "scientific revolution"? In the past few decades, the notion has become suspect among historians of science. Stephen Shapin begins his history of The Scientific Revolution by paradoxically stating, "There was no such thing as The Scientific Revolution, and this is a book about it." In the foreword to the Cambridge History of Science, volume 3, Lorraine Daston and Catherine Park "intentionally avoid" this "ringing three-word phrase," because "it is no longer clear that there was any coherent enterprise in the early modern period that can be identified with modern science, or that the transformations in question were as explosive and discontinuous as the analogy with political revolution implies, or that those transformations were unique in intellectual magnitude and cultural significance." Nicholas Jardine argues that "the 'Scientific Revolution' need not so much be rewritten as written off."' And Andrew Cunningham and Percy Williams suggest, under the title "De-centring the 'Big Picture, "' that the origins of modern science should not be sought in the seventeenth century but rather in the period 1760-1848, a period that Roger Hahn, Enrico Bellone, and others have called the "Second Scientific Revolution" (a term Cunningham and Williams disavow). ${ }^{9}$ That last suggestion is worth discussing further, since there are analogies between the processes they describe and developments in the humanities.

5. Floris Solleveld, "Conceptual Change in the History of the Humanities," Studium: Tijdschrift voor Wetenschaps- en Universiteitsgeschiedenis 7, no. 4 (2014): 223-39.

6. Lorraine Daston and Catherine Park, "Introduction: The Age of the New," in The Cambridge History of Science, vol. 3, Early Modern Science, ed. Lorraine Daston and Catherine Park (Cambridge: Cambridge University Press, 2006), 12-13.

7. Nicholas Jardine, "Writing Off the Scientific Revolution," Journal of the History of Astronomy 22 (1991): 311-18.

8. Andrew Cunningham and Percy Williams, "De-centring the 'Big Picture': 'The Origins of Modern Science' and the Modern Origins of Science," British Journal for the History of Science 26, no. 4 (1993): 407-32.

9. Roger Hahn, The Anatomy of a Scientific Institution: The Paris Academy of Sciences, 1666-1808 (Berkeley: University of California Press, 1971), 275; Enrico Bellone, A World on Paper: Studies on the 
Cunningham and Williams identify four factors in the period around 1800, which cumulatively shaped "science" in its modern form and led to a change in meaning of the term science. One can summarize them as follows: (a) "Science" applies to a new set of disciplines. Some of these are new formations; others set forth old practices under different names. (b) "Science" becomes a profession rather than a learned pursuit. (c) A new kind of site dedicated to the production of knowledge becomes common: the laboratory. (d) Questions about God, creation, and providence increasingly become irrelevant and/or inappropriate.

Do these developments occur in the humanities as well? Going from point $a$ to point $d$, the answers are Yes, um . . . Yes, and Yes. There are indeed $(a)$ new disciplines, or at least new denominations: art history, musicology, and linguistics are neologisms of this period; history, archaeology, and philology drastically change meaning. The emergence of $(b)$ scholarship as a profession is a less clear-cut case: scholars in Germany had already become academic personnel in the eighteenth century, while in France and England, independent scholars abounded until the 1870s. Still, there was a lasting institutional change in France after the Revolution and in Prussia around 1810. (c) Sites of knowledge production indeed emerge, in the form of seminars and public archives, although many scholars continue working from home. And in most fields $(d)$ questions about God become irrelevant and/or inappropriate, though more slowly than in natural science. Scholars can still be religiously inspired, but biblical chronology, the divine origin of language, and providential schemes of history are abandoned; religious orders lose much of their role in the production of knowledge; even theology gets historicized.

Why is this analogy relevant? Not only because the debate about the notion of a "scientific revolution" can be extrapolated to the domain of the humanities but also because the analogy equally works the other way round. To echo Cunningham and Williams, "like it or not, a big picture of the history of science is something which we cannot avoid" - and this applies to the history of the humanities as well. ${ }^{10}$

Now the standard account that most scholars have been following with regard to the history of the humanities is quite coherent, perhaps too conveniently so. That standard account assumes that around 1800 a historical turn took place in the study of language, history, culture, and art; that it was inspired by ideas about the expressive and organic character of language (Hamann, Herder, Humboldt), the cultural-historical relativity of ideas and customs (Vico, Herder), and the sublime character of art (Winck-

ScientificRevolution, trans. Mirella Giacconi and Riccardo Giacconi (1976; Cambridge, MA: MIT Press, 1980), originally published as Il mondo di carta: Ricerche sulla seconda rivoluzione scientifica (Milan: Mondadori, 1976).

10. Cunningham and Williams, "De-centring the 'Big Picture," 407. 
elmann, Schelling); that this turn is intimately connected with the rise of romanticism and nationalism; and that these ideas gained institutional foothold through the foundation of Berlin University (1810), which reversed the traditional hierarchy of the faculties and introduced a new model of academic freedom and "unity of research and teaching." Most researchers are aware that it is a slightly whiggish and Germanocentric account, but that is not the issue. ${ }^{11}$ The standard account is flexible enough to admit of a variety of approaches, perspectives, and nuances; even those who do not really believe in it can still follow it as a guideline, in accordance with the old wisdom that a bad plan is better than no plan.

Should we call this a "scientific revolution"? The problem is that scientific revolutions require not just an institutional but even more a conceptual change and that conceptual shifts are hard to pin down. In the humanities, there are hardly any strict units and measures, hence Kuhn's criterion of "incommensurability” does not apply. New ideas generally take time to spread and materialize, and their novelty depends on being seen as new. This makes scientific revolutions much more elusive entities than political revolutions. Nobody denies that the French Revolution or the Russian Revolution took place, for it was unambiguously clear that revolutionaries stormed the Bastille and the Hermitage, proclaimed the republic, and killed the monarch. What historians can disagree about is how they evaluate these events, what brought them about, and what the implications were. With conceptual shifts, that is all there is: the conceptual shift is in the implications. In that regard, pointing out scientific revolutions is more like pointing out renaissances, of which we now have-apart from The Renaissance - an Irish, Carolingian, Ottonian, Northern, Oriental, and maybe a few more varieties.

Floris Cohen, in The Scientific Revolution: A Historiographical Enquiry, urges his readers to make a distinction between the Scientific Revolution, a single event that marked the birth of modern science, and scientific revolutions, plural, the paradigm shifts within science as identified by Kuhn. ${ }^{12}$ Cunningham and Williams attempt to sketch a "big picture" without recourse to either of these notions; they disavow the notion of a Scientific Revolution because "to see the change this way is to stay within the old big picture, based on the same old assumptions about the nature of science." ${ }^{13}$ One could view the standard account in similar terms, as an account of "the birth of the modern humanities" that does not require the notion of a scientific revolution; the

11. For an overview of adherents and critique of this standard account, see Solleveld, "Conceptual Change."

12. Floris Cohen, The Scientific Revolution: A Historiographical Inquiry (Chicago: University of Chicago Press, 1994), 21.

13. Cunningham and Williams, "De-centring the 'Big Picture," 428. 
problem with that, however, is that the source material is replete with revolutionary rhetoric, either implicit or explicit.

At the same time, if there were indeed as many revolutionary proclamations as Meiners complains about, then that repetition in itself is self-defusing, because you can't have radical breakthroughs all the time. As German artist Martin Kippenberger used to say, "I can't cut off my ear every day." But if such rhetoric was indeed "a common thing to do," then there probably was a purpose to it. We do not have to take that rhetoric at face value, but it shows that the notion of a scientific revolution cannot be written off as whiggish and anachronistic.

My claim is that revolutionary rhetoric, as a type of speech act, can be seen as part of the process by which information is transformed into knowledge: a form of presentation through which things are presented as what Ian Hacking calls "candidates for truth-or-falsehood," through which criticism is expressed, and through which, occasionally, new styles of reasoning are introduced. ${ }^{14}$ That is not quite the same as positing a scientific revolution in the humanities around 1800; rather, it is intended as an account of conceptual and disciplinary shifts that makes no recourse to deep structures, world views, discursive formations, and other hypothetical collective-psychological entities. Whether one would then still call those shifts scientific revolutions, singular or plural, is a matter of taste.

\section{REVOLUTIONARY RHETORIC AS SPEECH ACTS}

One thing that one will not find in the revolutionary rhetoric of the period around 1800 is a proclamation of a scientific revolution in the humanities. The term humanities applied to a didactic program; the term Geisteswissenschaften did not yet exist. The nearest cognates were schöne Wissenschaften or belles lettres, domain designations that indicated a corpus of worthy subjects of study rather than a field of scholarly activity that one would want to revolutionize. And even for scholars who make no attempt at modesty, it is too broad; most revolutionary rhetoric, and the purportedly novel insights that are presented by it, pertain to a more specific field of study. Some nineteenth-century scholars, like Niebuhr and Ranke, saw themselves as finally writing history well rather than as revolutionizing their field; Friedrich Schlegel, in his claims of an "aesthetic revolution" and a "second Renaissance," was not aiming at discipline formation but at a wider cultural impact.

14. Ian Hacking, “'Style' for Historians and Philosophers,” in Historical Ontology (Cambridge: Cambridge University Press, 2002), 190; cf. Floris Solleveld, "What Books Are Made Of: Scholarship and Intertextuality in the History of the Humanities," in The Making of the Humanities, vol. 3, The Making of the Modern Humanities, ed. Rens Bod, Jaap Maat, and Thijs Weststeijn (Amsterdam: Amsterdam University Press, 2014), 265-79, esp. 277-78. 
Also, the concept of a "scientific revolution" had not yet been coined, and it is a term one would rather use in retrospect. This is indeed the case for the first two uses of révolution scientifique that I have been able to find, which are moreover quite local in their application: Peter Stephen du Ponceau's 1838 Volney Prize essay that argues that Adelung's Mithridates "fit une révolution dans la science [philologique],"15 and Augustin Thierry, who notes that the history of France has acquired a new theoretical character in the 1820s-1830s due to the French Revolution: "It seems that this scientific revolution was a consequence and a reflection of the social revolution accomplished fifty years ago, because it is made in its image; it has put an end to irreconcilable systems, like [the French Revolution] has destroyed, for always, the separation of orders." ${ }^{16}$ Also, these are remarks made in passing, rather than programmatic statements at the beginning, which is where the more activist declarations are generally to be found. But scholars before or around 1800 were in a position to proclaim things that came close: a New Science, a Copernican Revolution, an Oriental Renaissance. And the idea of breakthroughs in the world of learning had been reinforced by that seemingly least revolutionary genre of all, historia literaria, which had filed the history of letters (i.e., learning at large) into an overview of distinct fields of scholarship with a temporal progression.

One can distinguish between several kinds of revolutionary rhetoric: prospective, retrospective, critical, and implicit. It is prospective if it announces something that is still to be done; retrospective if it identifies something extant as a break or beginning point; critical if it does away with predecessors and thereby also implies a certain prospect for doing things differently; and implicit if it simply passes over predecessors in silence, as if the author were writing on a blank slate. Most often, these strategies are combined. The main place where one can find prospective rhetoric is in forewords and in texts with titles like Tableau, Treatise, Essay, Grundriß, Prolegomena. Retrospective rhetoric is sometimes included in these very same texts, when a few names (not too many) are invoked as antecedents; but it also can be used to create disciplinary histories, which in turn serve to define one's own position (this is what Destutt de Tracy does in defining idéologie, and Hippolyte Taine in proclaiming a "second revolution"). My main concern, in speaking of performative speech acts, is with the kind of rhetoric that creates these self-justificatory histories rather than with its later repetitions. Critical and implicit rhetoric sometimes go together in that the purportedly innovative work is presented with little or no references but preceded by a critical foreword or

15. Peter Stephen du Ponceau, Mémoire sur le système grammatical des langues de quelques nations indiennes de l'Amérique du Nord (Paris: Pihan de la Forest, 1838), 5.

16. Augustin Thierry, Considérations sur l'histoire de France (Paris: Garnier, 1840), 213. 
accompanied by dismissive reviews of earlier authors (this, for instance, is the rhetorical strategy of Grimm and Niebuhr).

What does it take for a programmatic statement to succeed or not? That is, of course, a judgment in hindsight; but the hindsight in nineteenth-century textbooks, or even in late eighteenth-century historia literaria, is not categorically different from ours. Christoph Meiners, in the passage quoted above, argued that such statements are genuine only if they present new things that had not yet been properly investigated. That gives us two possible criteria: intention and invention. But that is not enough: your intention and the novelty of your work also needs to be recognized, people need to follow suit, and that in turn should lead to new results. And even that is not enough: after all, they could also have come up with these new results anyhow. So an even stronger supplementary criterion is what the rhetoric excludes. These criteria can be listed as follows:

1. Intention: You can cause a breakthrough without intending to do so, but you cannot make a programmatic statement without intending to do so. Such expressions of intent, however, range from understatements like Bopp's that comparative grammar will yield "quite new explanations" to massive overstatements by figures like Friedrich Schlegel, who proclaims successively an aesthetic revolution, a new Romantic golden age, and an Oriental renaissance. ${ }^{17}$

2. Innovation: The rhetoric requires that something is presented as new, and significantly new - not just a new fact or insight but a whole new domain of facts or insights. However, whether they are indeed significantly new is something that you cannot decide on your own. "Novelty" depends on a set of critical and intertextual relations: first, with reference to the shortcomings of the extant literature, and second, through the judgment and reference by others.

3. Recognition: Typically, for such statements to be felicitous, you also need to be in a position to make them. Someone needs to listen and respond; that is, your statements need to be acknowledged as candidates for truth or falsehood. Accordingly, even criticism is a kind of recognition. The question is: recognition by whom? Moreover, even if there are established criteria for deciding whether your claims are correct, that does not yet imply a judgment on their novelty and significance.

17. Franz Bopp, “Analytical Comparison of the Sanskrit, Greek, Latin and Teutonic Languages," Annals of Oriental Literature 1 (1820): 2. 
4. Accumulation: A claim of revolutionary novelty that is broadly acknowledged but leaves the further edifice of knowledge largely untouched would still count as infelicitous. Ideas are not free-standing entities: they require application and elaboration. There is something circular in this criterion: conceptual innovation is at least partly destructive of what was previously accumulated as knowledge, and yet it should give rise to new accumulation.

5. Exclusion: If an idea is presented as new, that implies a comparison: what is the wrong, less relevant, "old" idea? What a programmatic statement excludes is a stronger criterion than accumulation - the accumulation could also be the result of something else, but if the previous practice continues regardless of being called into question, that indicates that the new insights were not as compelling as was claimed. To some extent, exclusion can count as the falsification criterion of programmatic statements-but only to some extent, because new ideas are rarely adopted by everyone at once.

In what follows, I will discuss four pairs of examples. The first pair (Vico and Gébelin) is from the eighteenth century, massively ambitious and largely prospective. The second (Kant and Idéologie) is from the turn of that century, self-consciously revolutionary but envisioning a transformation rather than a start from scratch. The third (Niebuhr and Thierry) is from the beginning of the nineteenth century, restricted to one discipline, and combines critical and implicit rhetoric. A shorter section is devoted to retrospective rhetoric, which becomes a vessel for grand visions with Hippolyte Taine and for more realistic hopes in the last great historia literaria. For reasons of space, I cannot do justice to the rhetoric of Friedrich Schlegel, who makes no less than three different revolutionary proclamations in a period of twelve years, first of an aesthetic revolution through the study of the Greeks, then of a universal Romantic poetry, then of a second Renaissance inspired by Sanskrit philology. Suffice to say here that Schlegel's proclamations have an uncannily high success rate but that he always gets something different from what he wanted.

\section{THE AFTERLIFE OF GIAMBATtISTA VICO}

The appropriate starting point would be Giambattista Vico. Preceding most of the other revolutionary rhetoric in this overview by at least half a century, his proclamation of a new science is unique in its self-conscious outspokenness as well in scope. Famously, according to Vico, "man could only know what he himself created"; and therefore he argued for a New Science in which philosophy, philology, and history are combined. In the first edition (1725) his proclamation simply reads that "we have 
hitherto lacked a science that is both a history and philosophy of humanity." 18 In the third edition (1744) Vico gets more verbose:

Here philosophy examines philology (that is, the doctrine of everything that depends on the human will; for example, all histories of the languages, customs and deeds of peoples in war and peace), of which, because of the deplorable obscurity of causes and almost infinite variety of effects, philosophy has had almost a horror or treating; and reduces it to the form of a science by discovering in it the design of an ideal eternal history traversed in time by the histories of all nations. ${ }^{19}$

This came together with a frontispiece in which the "idea of his work" was presented, the explication of which fills the entire first chapter. The first edition, moreover, presented itself in capitals to THE ACADEMIES OF EUROPE IN THIS ENLIGHTENED AGE.

There is something of a Sleeping Beauty story about Vico. When he died in poverty in 1744, the learned world outside Naples hardly took notice: no notices appeared in scholarly journals, and no obituaries were read at royal or local academies. Eighty years later, his work was translated into German and French and invoked by Quinet and Michelet as the source of principles that could turn history into a science; ${ }^{20}$ in the 1860s, Michelet retrospectively called him "his sole guiding spirit,"21 and a statue was raised in the Naples public gardens. Anthony Grafton's foreword to the Penguin edition of the New Science compares the book to Newton's Principia. ${ }^{22}$

In fact, Vico was never quite forgotten. Rather, his eighteenth-century readers did not know what to do with him. Montesquieu and Goethe owned copies of the Scienza nuova; Hamann and Jacobi discussed him in correspondence; Herder mentions him in the Briefe zur Beförderung der Humanität. ${ }^{23}$ Jean Le Clerc, who had favorably reviewed

18. Giambattista Vico, The First New Science, trans. Leon Pompa (1725; Cambridge: Cambridge University Press, 2002), 18.

19. The New Science of Giambattista Vico, trans. Thomas Bergin and Max Fisch (1744; New York: Cornell University Press, 1948), 6.

20. Edgar Quinet, introduction to Johann Gottfried von Herder, Philosophie de l'histoire de l'humanité, trans. Edgar Quinet, vol. 1 (Paris: Levrault, 1827), 7-71; Jules Michelet, Histoire romaine, vol. 1 (Paris: Hachette, 1831), vi-vii, and Introduction à l'histoire universelle (1831; Paris: Hachette, 1834), 229-30. Michelet was the author of the 1827 French translation, Principes de la Philosophie de l'Histoire.

21. "Je n'eus de maître que Vico." Jules Michelet, "Préface de 1869," Histoire de France, vol. 1 (Paris: Librairie Internationale, 1871), 11.

22. Giambattista Vico, New Science, trans. David Marsh (London: Penguin, 1999), xi.

23. For an overview, see Max Fisch's introduction to The Autobiography of Giambattista Vico, trans. Max Fisch and Thomas Bergin (Ithaca, NY: Cornell University Press, 1944), esp. 67-80. 
two earlier works by Vico, was sent a review copy - to no effect. ${ }^{24}$ The Göttingen writers of compendia, who read everything, knew who he was: he is included, with compliments for his originality and caveats for his idiosyncrasy, in Eichhorn's Geschichte der Litteratur (1805-11) and Wachler's Geschichte der historischen Forschung und Kunst (1812-20). But only two people outside Italy seriously referred to Vico as a secondary source in the eighteenth century, and they both do so in support of a conjectured or invented mythical past: Michael Denis, in his German translation of Ossian (derived from Cesarotti's Italian version); and Antoine Court de Gébelin, the pasigraphic reconstructor of the Wisdom of the Ancients, about whom more is discussed below.

The remarkable fact is that Vico came to be discussed in much more detail after the publication of Friedrich August Wolf's Prolegomena ad Homerum (1795) and Barthold Niebuhr's Römische Geschichte (1811-12) — and in immediate response to these works. The shift occurs in two very similar texts from 1807 and 1816: the first, by Wolf, appears in the first issue of Museum der Alterthums-Wissenschaft; the second, a review of Niebuhr's Römische Geschichte by the Swiss philologist Johann Caspar von Orelli. Wolf, under the title "Giambattista Vico über den Homer," summarizes the third book of the Scienza nuova on the "discovery of the true Homer." ${ }^{25}$ In a blurry mix of paraphrase and comment, Wolf draws up a long list of points on which Vico had new ideas, made mistakes, or overlapped with his own Prolegomena. Wolf claims to have been first alerted on Vico by a letter from Cesarotti, the Italian translator of Ossian and the Iliad, who saw strong analogies between the Prolegomena and the Scienza nuova and subsequently sent him a copy. ${ }^{26}$ Wolf's judgment on Vico is not without hesitations: "Historische Strenge ist zwar nirgends in diesem Räsonnement; kaum scheint Vico davon eine Idee gehabt zu haben. Alles hat eher das Ansehen von Visionen." ${ }^{27}$ Also, Vico is not mentioned in Wolf's Darstellung der Alterthums-Wissenschaft, which appeared in the same volume. Still Wolf concludes that if Vico had written in English, he would have been famous.

Orelli finds Wolf's judgment still a bit too grudging. Reviewing Niebuhr, he does the same with regard to Roman history, pointing out parallels between Vico and Nie-

24. John Robertson, The Case for the Enlightenment: Scotland and Naples, 1680-1760 (Cambridge: Cambridge University Press, 2005), 200-208.

25. Friedrich August Wolf, "Giambattista Vico über den Homer," Museum der AlterthumsWissenschaft 1 (1807): 555-70.

26. Cesarotti refers favorably to Vico in both translations; the footnotes of Michael Denis, Ossians und Sineds Lieder (1784), in which Ossian is read in Viconian terms, were also borrowed from Cesarotti's Ossian.

27. Wolf, "Vico über den Homer," 570. 
buhr, in a neat list of sixteen points, with long Italian quotes. ${ }^{28}$ According to Orelli, Vico's ideas on Roman history are even more worthwhile than those on Homerenough so, Orelli concludes, to warrant a German translation of Vico's autobiography and at least part of the Scienza nuova.

What we see here is, in effect, backward causation. It could be that Wolf had actually known about Vico before; but it doesn't really matter. At that point Vico's "visions" were no longer candidates for truth or falsehood; they were being acknowledged as adumbrations of Wolf's and Niebuhr's insights into Greek philology and Roman history, thereby reinforcing rather than undermining the rhetoric by which Wolf and Niebuhr very self-consciously styled their works as foundational texts.

\section{THE UNIVERSAL LANGUAGE SCHEMES OF COURT DE GÉBELIN}

If Vico was an isolated figure at the margins of the Republic of Letters, Antoine Court de Gébelin was a sensation at the heart of the learned world in late ancien régime Paris. His Monde primitif spread throughout France and beyond, in spite of the cost of nine large quartos full of plates. In it, he announced a reconstruction of the self-evident, pictographic, universal language of the ancients, through which all classical texts and languages would be made transparent and all mythology rendered reasonable:

With the help of these researches, tout change de face. Nothing in each language which does not have its reason, and does not yield access easily to us because of that. . . The allegorical Genius of Antiquity, its symbols, its Mythology, once established in their first lustre, \& no longer offering a mass of absurd fables, will be an infinite resource not only for the understanding of antiquity, but also for the perfection of Arts, Poetry, Painting, \&c. ${ }^{29}$

And that insight into "le Génie allégorique de l'Antiquité" was only the least of the advantages of his analysis; it would also, by guiding back "les Connoissances humaines aux besoins des Hommes," lead to true public felicity. ${ }^{30}$

Monde primitif is a work of immense erudition: Gébelin's reconstructions incorporate general grammar, etymology, the physiology of the language organs, physiocratic theory, numismatics, calendars, the history of the alphabet, Greek mythology, the tarot, and more. It was also, of course, science fiction. On the one hand, he formu-

28. Johann Caspar von Orelli, review of Römische Geschichte, Ergänzungsblätter zur Jenaischen allgemeinen Literatur-Zeitung 2, nos. 91-92 (1816): 337-46.

29. Antoine Court de Gébelin, Monde primitif analysé et comparé avec le monde moderne, vol. 1 (1773; Paris: Boudet et al., 1777), 91.

30. Ibid., 98. 
lates very sensible principles for language comparison on the basis of roots, makes a taxonomy of language families, and even formulates (very imprecise) sound shift laws; on the other, his table of an Alphabet hieroglyphique et primitive de XVI. lettres begins with the letter $A$, which looks like both the Chinese character for "man" and Hebrew aleph, and which is also, naturally, the first letter of the Greek word for "man." 11

Gébelin's claims were far-fetched, but they were not pure idiosyncrasy. The Hebrew alphabet indeed originates from pictograms, which came to stand for the first letter of what they depict; in hieroglyph and cuneiform (then not yet deciphered) such phonetic, logographic, and pictographic signs even coexist. In tracing vowels and consonants back to their "original meaning," he was simply setting forth Charles de Brosses's Traité sur la formation méchanique des langues (1765). His idea that the "primitives" are not that primitive gave important inspiration to his secretary and pupil Peter Stephen du Ponceau, who went to America to fight in the War of Independence and was later a pioneer in the comparative study of Native American languages. Sixty years later, in the Volney Prize essay in which he points out the complicated polysynthetic grammatical structure of these languages, Ponceau still praises his erstwhile mentor. ${ }^{32}$

At the time of his somewhat lurid death in 1784, the Monde primitif still unfinished, Gébelin's reputation had begun to wane. All the same, he is still taken seriously in the decades afterward by scholars like Thomas Astle, who borrowed a less speculative overview table of primitive alphabets for The Origin and Progress of Writing (1784); Dugald Stewart, who agrees with some of his etymological theories and finds others worth refuting, ${ }^{33}$ and Jean-Denis de Lanjuinais, who published anew Gébelin's own summary of volumes 2 and 3 of the Monde primitif, the Histoire naturelle de la parole, anew in 1816. A few mystics, like Delisle de Sales and Fabre d'Olivet, set forth his speculations about lost Ancient Lore.

Gébelin was of course by no means the first to propose a universal language scheme-Wilkins, Dalgarno, and Leibniz had been doing so in the seventeenth century. But while these were intended as mathematical schemes, Monde primitif is a largely philological project. As such, it is unique in its inclusivity, in its somewhat Viconian ambition to change les Connoissances humaines at large. Take away the suggestion of esoteric ancient lore, and it has much in common with the program of Idéologie in the late 1790 s and early 1800 s.

31. Antoine Court de Gébelin, Monde primitif analysé et comparé avec le monde moderne, vol. 3 (Paris: Boudet et al., 1776), plates 4 and 5.

32. Du Ponceau, Mémoire sur le système grammatical, 22.

33. Dugald Stewart, Elements of the Philosophy of the Human Mind, vol. 3, Works 6 (1792; Cambridge: Hilliard \& Brown, 1829), 30-34, 69-71. 


\section{KANT AND THE TRANSFORMATION OF PHILOSOPHY}

The most unambiguously successful revolutionary rhetoric in scholarship around 1800 was Kant's. Whether philosophy belongs to the domain of the humanities is an open question even today; Kant certainly did not think of his work as schöne Wissenschaften or belles lettres. But his "Copernican Turn" had repercussions for the domain of what became the Geisteswissenschaften at large:

Now the concern of this critique of pure speculative reason consists in that attempt to transform the accepted procedure of metaphysics, undertaking an entire revolution according to the example of the geometers and natural scientists. It is a treatise on the method, not a system of the science itself; but it catalogs the entire outline of the science of metaphysics, both in respect of its boundaries and in respect of its entire internal structure. ${ }^{34}$

This passage from the Kritik der reinen Vernunft is from the introduction of the second edition (1787); in the first edition (1781), the term revolution does not occur. It is remarkable that Kant presented his famously dense Critiques only as an "outline"; the "scientific system" proper, presumably, would be in the application of his categories to the analysis of knowledge and ethics at large.

The way in which Kant's rhetoric was acknowledged was not quite by literally endorsing it. Few readers were ever really satisfied with his notions of a Ding an Sich, of synthetic a priori judgment, or of the self. Reinhold, his first great expositor, attempted to reduce the critical philosophy to a first principle; Fichte built a Wissenschaftslehre on the idea of an I that determines; Schelling came up with a variety of systems aimed at the reconciliation of mind and nature and spent the second half of his life complaining that Hegel's dialectic was originally his (Schelling's) idea. In short, Kant's revolutionary rhetoric gave rise to more revolutionary rhetoric, far beyond what Kant intended or would have perceived as proper philosophical science.

The story of Kant's progeny in German Idealism is well known and massively documented. A less familiar, but perhaps even more telling indication of the impact of his philosophy is in histories of philosophy in the first decades of the nineteenth century. In all of these, Kant becomes the culmination point. Tennemann's eleven-volume Geschichte der Philosophie (1798-1819) uses Kant as a standard to measure all previous philosophy by, and the second half of Buhle's Geschichte der neuern Philosophie (1801-5) is devoted to "Philosophie des 18. Jahrhunderts bis Kant." De Gérando's Histoire comparée des systèmes de philosophie (1804) presents Kant's work as the solution to the 
shortcomings of earlier systems, though it also needs emendation. Even Dugald Stewart, who finds Kant overrated and does not really understand him (he admits that he knows no German and has to rely on De Gérando and a sloppy Latin translation), still devotes to him the penultimate chapter of his Dissertation exhibiting a General View of the Progress of Metaphysical, Ethical and Political Philosophy since the Revival of Letters (originally the preface to the supplement of the Encyclopaedia Brittanica). ${ }^{35}$ Hegel's lectures on the history of philosophy (1819-30), more pompously, teach that "apart from Kant, Fichte and Schelling, there is no [modern] philosophy." ${ }^{36}$ Together, these histories also further shape the idea of philosophy as an independent discipline, or if you like, Wissenschaft. ${ }^{37}$

The implications of Kant's philosophy for historical and philological research are harder to pin down. There are a few instances of unmistakably Kantian terminology: K.O. Müller, who applies a Kantian idea of beauty to classical antiquity in his Handbuch der Archäologie der Kunst (1830); $;^{38}$ Gottfried Hermann, who criticizes Creuzer's notion of mythology as a "confusion of categories"; ${ }^{39}$ August Pott, whose system of conjugations is built on Kantian categories (quantity, quality, modality, relation). ${ }^{40}$ Georg Gervinus is quite critical of Kant's view of history in Grundzüge der Historik but still begins his book with the very Kantian stipulation that "Die Dinge erscheinen uns entweder nach ihrer Wirklichkeit, oder nach ihrer Möglichkeit, oder nach ihrer Notwendigkeit" and posits an equally Kantian regulative idea of teleology as a "necessary condition" for historiography. ${ }^{41}$

35. Dugald Stewart, Dissertation exhibiting a General View of the Progress of Metaphysical, Ethical and Political Philosophy since the Revival of Letters, Works 6 (1815-21; Cambridge: Hilliard \& Brown, 1829), $358 \mathrm{ff}$.

36. Georg Wilhelm Friedrich Hegel, Vorlesungen über die Geschichte der Philosophie, ed. Carl Michelet, vol. 3 (1832; Berlin: Duncker \& Humblot, 1844), 485, 553.

37. On the shaping of philosophy in the modern sense through Kant and the historiography of philosophy, see Richard Rorty, Philosophy and the Mirror of Nature (Princeton, NJ: Princeton University Press, 1979), chap. 3; and Ulrich Schneider, Die Vergangenheit des Geistes: Eine Archäologie der Philosophiegeschichte (Frankfurt: Suhrkamp, 1990)

38. Karl Otfried Müller, introduction to Handbuch der Archäologie der Kunst, 4th ed. (1830; Stuttgart: Heitz, 1887).

39. Gottfried Hermann, Über das Wesen und die Behandlung der Mythologie: Ein Brief an Herrn Hofrath Creuzer (Leipzig: Fleischer, 1819), 7-11, et passim.

40. August Pott, Etymologische Forschungen auf dem Gebiete der Indo-Germanischen Sprachen, vol. 2 (Lemgo: Meyer, 1836), 653.

41. Georg Gervinus, Grundzüge der Historik (Leipzig: Engelmann, 1837), 14-15, 65-66. 


\section{IDÉOLOGIE AS A PROJECT OF REFORMULATION}

The term Idéologie was coined in response to the complete reorganization of education and research during the French Revolution. That reorganization effectively took shape only after Thermidor. In the Law on Public Instruction of 3 Brumaire, An IV (October 25, 1795), a complete national system of education is laid out, from base to top: (1) écoles primaires, (2) écoles centrales, (3) écoles spéciales, and (4) an Institut national des sciences et des arts. ${ }^{42}$ The term universities does not occur in this law; universities were not explicitly abolished but rather were rendered obsolete. In their stead came "special schools" that offered higher professional education in ten fields, including geometry, medicine, political science, and antiquities. Meanwhile, the Institut national replaced the old academies and was divided into classes of sciences physiques et mathématiques, sciences morales et politiques, and littérature et beaux-arts.

"Moral and political science" was a novelty: it brought together history, law, geography, political economy, "social science," and analyse des sensations et des idées. For the eight years of its existence, the class on moral and political science became the vestige of a group of thinkers pejoratively called the Idéologues. In a Mémoire published in its first volume of proceedings (1798), Antoine Destutt de Tracy laid out a program for founding the study of man in the "analyse des sensations et des idées," which according to Destutt now was a field of study on its own. With the work of Locke and Condillac, he stated, the science of ideas was now no longer "une science hypothétique" founded on "suppositions frivoles"; it was susceptible of the same degree of certitude as the mathematical sciences; it was, moreover, "la première de toutes [les sciences] dans l'ordre généalogique"; ${ }^{43}$ but it had not yet found its Newton, and it still needed a proper name: "One could call it psycologie. Condillac seemed disposed towards that. But that word, which means science of the soul, seems to suppose a knowledge of that entity, which you certainly do not flatter yourself to possess; and it would have the further inconvenience of causing people to believe that you occupy yourself with the vague investigation of first causes . . I I would therefore much prefer that we adopt the name idéologie, or science of ideas." ${ }^{44}$

In the following years, Destutt wrote three volumes of Eléments d'idéologie (18015), intended as high school textbooks; they are addressed, in somewhat Cartesian fashion, to "les jeunes gens" whose minds have not yet been corrupted by wrong ideas.

42. James Guillaume, Procès-verbaux du Comité d'instruction publique de la Convention nationale, vol. 6 (Paris: Imprimérie Nationale, 1907), 793-800.

43. Antoine Destutt de Tracy, "Mémoire sur la faculté de penser," in Mémoires de l'Institut National des Sciences et des Arts pour l'An IV: Sciences morales et politiques, vol. 1 (Paris: Baudouin, An VI [1798]), 288, 286.

44. Ibid., 323-24. 
They are effectively a reformulation of the old trivium: idéologie proper as the science of the relations between ideas, grammaire générale as that of the expression of ideas, and logique as the purification from false ideas.

Idéologie was not just intended as a new science but also as an ideal of moral selfperfection through the clarification of ideas. Thus Destutt's friend Cabanis, who had been trained as a medical doctor, outlined the integrated physiological, intellectual, and moral study of man in his Rapports du physique et du moral de l'homme (1802); Abbé Grégoire argued for language unification and Black emancipation. Arguably, it was not so much a new science as a program of reformulation. The most telling example of this is De Gérando's well-received Histoire comparée des systèmes de philosophie, relativement aux principes des connaissances humaines (1804), which reformulates the history of Western philosophy in ideological terms. The first part is chronological, from the Presocratics to Kant and his successors, and ends with endorsing Kant's claim of a revolution in philosophy while criticizing the scholasticism and speculative idealism of his offspring. The second part is largely an ideal, typical presentation of the positions reconciled by Kant: rationalism, dogmatism, idealism, materialism, skepticism, and empiricism. It concludes with an "ideological" reading of Kant to counter the idealist tendencies in his philosophy, in which the Kantian ideas become psychological archetypes rather than transcendental entities.

By that time, the class of moral and political sciences had been closed down. Napoleon, whose coup d'état had been welcomed or even aided by most Idéologues, found their political theorizing a nuisance and sidetracked them into well-paid sinecures. After his fall, they continued their project of reformulation but could not regain political momentum. Destutt de Tracy added two volumes to his Éléments and published a chapter-by-chapter commentary on Montesquieu's Esprit de lois, essentially an update. Abbé Grégoire drew up a plan for reinventing an international Republic of Letters through Parisian institutions; it fell quite dead-born from the press. De Gérando embraced a Christian philosophy of charity and self-education in his Du perfectionnement moral, ou de l'éducation de soi-même (1823) and started rewriting his history of philosophy along those lines; it grew out of hand so that the four volumes on modern philosophy came out only posthumously, in 1847 .

\section{NIEBUHR AND THIERRY WRITE OFF THEIR PREDECESSORS}

Barthold Niebuhr's Römische Geschichte (1811-12) is probably the best example of implicit revolutionary rhetoric. There is hardly any reference to modern scholars in his text. In the preface, he explains, 
I have not used modern works on Roman history either during my research, or in the course of my lectures. This has spared my historical account from the temptation toward controversies, which the shape of the work could not bear and which do not contribute much to science in themselves, and could better be replaced by the most complete investigation possible. If the opinions set forth have been proven to be true or the most probable, then no further refutation of the opposite is necessary. ${ }^{45}$

Niebuhr's contention is that the whole of early Roman history is "ungewiß und verfälscht" and that accordingly the historian should separate fact from fiction rather than reproduce the sources as they are: "der Historiker aber bedarf positives." That same insight had in fact been formulated more than seventy years before in Louis de Beaufort's Dissertation sur l'incertitude des cinq premiers siècles de l'histoire romaine (1738), as Niebuhr grudgingly admits; but since Beaufort had not delivered enough of a "positive history," Niebuhr puts him down as "mehr Gewährsmann als Vorgänger."46

Gibbon is the only predecessor whose merit Niebuhr fully recognizes - so much that he explicitly intends to "stop where Gibbon starts." In the end, Niebuhr never got that far; the much delayed third volume doesn't even reach the end of the Republic. In the second edition (1829) he is considerably milder toward predecessors like Beaufort.

Deadly silence was not Niebuhr's only rhetorical weapon. Against Arnold Heeren, then the leading German historian, he used open violence. In 1813, he reviewed the third volume of Heeren's Ideen über die Politik, den Verkehr und den Handel der vornehmsten Völker der alten Welt - the volume dealing with ancient Greece. Heeren's work can be seen as a German brand of histoire philosophique: it consists of general observations and analysis rather than a full chronological account. According to Niebuhr, that kind of pick-and-choose was not enough:

We hold the profession of the historian to be ein heiliges Amt, a profession so serious that he should weigh each word as if speaking in court. ${ }^{47}$

45. Barthold Niebuhr, Römische Geschichte, vol. 1 (Berlin: Realschulbuchhandlung, 1811), xii. The English translation (1835) includes only the preface to the second edition.

46. Ibid., ix-x, xii. In fact Beaufort had later written a two-volume Plan Géneral of the Roman Republic that, if not an account of the Roman past at large, was most definitely a serious attempt at historical reconstruction.

47. Barthold Niebuhr, review of Arnold Heeren, Ideen über die Politik, den Verkehr und den Handel der vornehmsten Völker der Alten Welt, vol. 3, Ergänzungsblätter zur Jenaischen allgemeinen LiteraturZeitung 1, nos. 7-12 (1813): 53. 
If the author of a work on the history of antiquity, purporting to present something new, would have another audience in mind than that of the most severe experts: then this would result in such faulty mannerism, that such a work must be regarded as lost for science at least. ${ }^{48}$

A similiar critique was later levied by A. W. Schlegel against the volume on India. ${ }^{49}$ Heeren did not follow Niebuhr's demand to revise his volume and "leave no stone upon the other"; instead, he spent the remaining twenty-nine years of his life revising the rest of the Ideen, supervising the Heeren-Ukert series of European history, and editing the Göttingische Gelehrte Anzeigen. ${ }^{50}$ Niebuhr did not achieve much after the first two volumes of Römische Geschichte either, similarly caught up in revisions and unable to live up to his own requirements. ${ }^{51}$ His work stands out, in spite of its lengthy ruminations, as a coherent chronological history with high scholarly aspirations, something that simply does not occur in German historiography before the nineteenth century. Arguably, the novelty of Niebuhr's approach is not in his demand for methodological rigor but in his way of putting a book together.

Ranke, a decade later, did much the same for modern history what Niebuhr had been doing for classical history. His rhetoric is even more implicit; it is pretty much summed in the four famous words wie es wirklich gewesen. By that phrase, he disavows not only the classical ideal of historia magistra vitae but also the cultural-political agenda of histoire philosophique, without even naming his eighteenth-century predecessors. His appendix "Zur Kritik neuerer Geschichtsschreiber" to the Geschichten der romanischen und germanischen Völker von 1494 bis 1519 (1824) is concerned with Guicciardini, Macchiavelli, and other historians from the sixteenth century, that is, contemporaries of the events they describe; Robertson, who had covered partly the same period in his History of Charles $V$, is not even mentioned.

A more methodic strategy of writing off all predecessors was followed by Augustin Thierry in his Lettres sur l'histoire de France (1820/1827). In the first ten letters, serialized in the Courier Français, he discusses at length how previous historians of France have misrepresented the medieval past and how late eighteenth-century histoire phi-

48. Ibid., 50.

49. August Wilhelm Schlegel, “An der Professor Heeren in Göttingen: Über die Abtheilung von den Indern in seine Ideen über die Politik, den Verkehr und den Handel der vornehmsten Völker der alten Welt," Indische Bibliothek 2 (1827): 373-473.

50. See Horst-Walter Blanke, "Verfassungen, die nicht rechtlich, aber wirklich wird: A. H. L. Heeren und das Ende der Aufklärungshistorie,” Berichte zur Wissenschaftsgeschichte 6 (1983): 14364, esp. 154-55.

51. Wilfried Nippel, "Barthold Georg Niebuhr: Ein schwieriger Gründervater," in Klio dichtet nicht: Studien zur Wissenschaftsgeschichte der Althistorie (Frankfurt: Campus, 2013), 93-130. 
losophique doesn't mark an advance in this regard. In a show of historical hypercorrectness, Thierry speaks of Clovis as Chlodovegh and Charlemagne as Karl-le-Grand. In the preface to the book version, seven years later, his rhetoric gets Cartesian:

I attempt to efface from my mind all that they have taught me, and enter, so to speak, in rebellion against my masters.

But on the same page he also notes that the situation has changed since 1820, and aligns himself with a new generation, whose works have appeared since:

works that mark a true revolution in the way of writing the history of France. M. de Sismondi for the science of facts, M. Guizot for his broad and refined insights, M. de Barante for truthful storytelling, have opened a new road; the best thing to do now is to follow in their suit. ${ }^{52}$

In the fifteen letters added to the book version, Thierry elaborates how such a history of France should be written. Unlike Niebuhr, his agenda is explicitly political: it should be a history of communes rather than kings and a history of how liberties were gained and lost.

\section{RETROSPECTIVE RHETORIC: POINTING OUT "TURNING POINTS"}

Revolutionary rhetoric and canon formation are two sides of the same coin. Prospective proclamations require later retrospective recognition for their fulfilment. But the revolutionary rhetoric does not always follow that order; sometimes the retrospective identification of a "turning point" becomes a performative act of its own right, and quite as often such precedents are invoked-prospectively — as examples to emulate. Hippolyte Taine's Histoire de la littérature anglaise (1863) is a salient example. Taine propounds a mechanistic approach to literary history, based on three factors: race, milieu, moment - and he chooses English literature as a case study because it is one of the few that shows a continuous line of development. For Taine, this projected scientification marks the second step in the transformation of history:

History, within a hundred years in Germany, and within sixty years in France, has undergone a transformation owing to a study of literatures. The discovery has been made that a literary work is not a mere play of the imagination, the isolated caprice of an excited brain, but a transcript of contemporary manners

52. Augustin Thierry, Lettres sur l'histoire de France, 4th ed., CEuvres 1 (1820/27; Paris: Garnier, 1866), 2-3. 
and customs and the sign of a particular state of intellect. . . Such is the first step in history. This step was taken in Europe at the end of the last century when the imagination took fresh flight under the auspices of Lessing and Walter Scott, and a little later in France under Chateaubriand, Augustin Thierry, Michelet, and others. We now come to the second step. ${ }^{53}$

Taine's is a classic example of a programmatic statement, made in the preface of a book that is intended to become a standard work. But such retrospective-prospective speech acts also occur in less conspicuous places.

Historia literaria, or the history of learning, was itself outlined programmatically in the Latin version of Bacon's The Advancement of Learning (1605/1623). In the next two centuries, it developed into a genre of bibliography raisonnée, culminating in the massive Göttingen Geschichte der Künste und Wissenschaften seit der Wiederherstellung desselben bis zum Ende des achtzehnten Jahrhunderts (ca. 100 vols., 1796-1820). In the section on Poesie und Beredsamkeit (12 vols., 1801-19), Friedrich Bouterwek aims to revivify German literature by furnishing it with examples of Romantic - that is, Spanish, Portuguese and Italian - literature as an alternative to sterile French Classicism. While he is writing, the Romantic revolution takes place behind his back. In the penultimate volume (the last one is a register), he puts down earlier German authors of Litteraturgeschichte as "pedantische Compendienschreiber" - only to conclude, on the very last page, that the generation of the Schlegel brothers pays him a similiar compliment. ${ }^{54}$

Another section of the Göttingen project, Ludwig Wachler's Geschichte der historischen Forschung und Kunst (5 vols., 1812-20), gets programmatic only in the fourth volume, when it sums up all the progress that has been made in historiography since the middle of the last century. The French have created wholly new roles for the historian in shaping and addressing public opinion through "überall vernehmbahrer, lebendig thätiger Ausdruck des Gefühls für Würde der Menschheit"; ${ }^{55}$ the British (Hume, Robertson, Gibbon) have perfected the historical art to such a degree that they are "Muster der historischen Kunst für ganz Europa." ${ }^{56}$ The Germans, finally, are now in a position to combine their "unverkennbare Überlegenheit in Gründlichkeit, Voll-

53. Hippolyte Taine, History of English Literature, trans. Henri van Laun (Edinburgh: Edmonston \& Douglas, 1872), 1, 4 .

54. Friedrich Bouterwek, Geschichte der Poesie und Beredtsamkeit seit dem Ende des dreizehnten Jahrhunderts, vol. 11 (Göttingen: Röwer, 1819), 505-7, 533.

55. Ludwig Wachler, Geschichte der historischen Forschung und Kunst: Seit der Wiederherstellung derselben bis an das Ende des achtzehnten Jahrhunderts, Tl. II.ii (Göttingen: Röwer, 1818), 424.

56. Ibid., 610 . 
ständigkeit und Methode" with newly awakened national spirit, philosophy, Gefühl, Verstand, and Einbildungskraft. ${ }^{57}$ Thanks to an immense increase in historical resources and huge progress in the auxiliary sciences, German historians can now combine Forschung and Kunst.

\section{CONCLUSION}

The list can be extended further. One could add Dutch philologist Van Lennep, who sought to make classical philology more scientific through a set of twenty-four "certas \& fixas leges analogiae," ${ }^{58}$ couched in legal rhetoric; Schleiermacher, whom Dilthey turns into "the founder of hermeneutics"; Humboldt, whom Droysen called "the Bacon of history"; and a dozen grammaires générales, universal grammars, and Allgemeine Sprachlehren demarcating the science of the principles of grammar from the art of learning a language. For the British case, one could add Horne Tooke's claim to dispel "metaphysical imposture" through a new theory of language, or Whiter's Etymologicon Universale, which purports to bring etymology from a state like that of the "imperfect art of Arithmetic" to one on a par with "the science of Algebra." ${ }^{59}$ Wolf, Schlegel, histoire philosophique, and German Idealism have only been mentioned in passing. As it is, these are enough examples to show that revolutionary rhetoric is ubiquitous in the humanities around 1800.

These examples also confirm a few observations made in the introductory paragraphs. It seems that the rhetoric is more successful if it cuts paper trails; if it points out what aspects of earlier scholarship it disavows. Accumulation and reformulation, obviously, are not enough; one could turn Meiners's weary complaint that opened this article against him, as well as against Gébelin, and to some extent against the Idéologues. Methodological and epistemological awareness can be taken for granted; strikingly, Gébelin's fantastic claims are preceded by seventy-five well-argued pages about method, whereas Ranke and Niebuhr are very brief on method and epistemology.

How representative are these examples? They are, evidently, mainly German and French, but they do cover most fields within or at the margins of the humanities. That does not yet show that revolutionary rhetoric was particularly widespread in this period or different in kind from what it was around 1700 or around 1860-70. My general impression is that it was. The rhetoric that surrounds the Querelle des anciens et des

57. Ibid., 433.

58. Johan Daniel van Lennep, In analogiam linguce Grocee (Utrecht: Paddenburgh, 1779), 302-19. The work includes his 1751 inaugural lecture, in which he had adumbrated this approach.

59. John Horne Tooke, Epea Pteroenta; or, The Diversions of Purley (1786-1805; London: Tegg, 1840), 684; Walter Whiter, "Preliminary Discourse," in Etymologicon Universale, or Universal Etymological Dictionary, vol. 1 (Cambridge: Cambridge University Press, 1811), 3. 
modernes, the Battle of the Books, and the controversy between Maurists and Bollandists is not that much about carving out new disciplines or proclaiming new sciences. It would, therefore, be much more anachronistic to read that rhetoric as proclamations of a scientific revolution. There is, moreover, a rhetoric that demarcates science from art in the study of language that goes back to Port-Royal and Wilkins in the 1660s, and a recurrence of Baconian references throughout the seventeenth to nineteenth centuries - so there are continuities. Around 1870, a great wave of institutionalization and professionalization takes place, which comes with a lot of rhetoric denouncing earlier approaches as unscientific - but that rhetoric generally serves for demarcation within a discipline, and it typically invokes antecedents. ${ }^{60}$ If one looks for an institutional counterpart in the humanities for Cunningham and Williams's big picture, one could just as well find it here, if only because it is also then that the notion of Geisteswissenschaften gains wider currency. But there is no huge shift in method, publication format, or disciplinary designations in this later period, at least not in Europe.

Even when successful as speech acts, these examples do not show that there was a scientific revolution in the humanities around 1800. Some of the objections against that notion remain: it entails some sort of mysterious (paradigm) shift or (epistemic) break; it unfairly reduces what came before to pseudoscience; and it suggests a kind of finalism in which the outcome is science as it should be. But as the broad trend of revolutionary rhetoric in the humanities shows, it is only a slight reformulation of how the authors perceived their own work; and given the profound transformation of scholarship around 1800, this was not a delusion. I can think of no knock-down argument why talk of a scientific revolution in the humanities would be true or false. At any rate, it should not be written off.

\section{WORKS CITED}

Bellone, Enrico. (1976) 1980. A World on Paper: Studies on the Scientific Revolution. Translated by Mirella Giacconi and Riccardo Giacconi. Cambridge, MA: MIT Press. Originally published as Il mondo di carta: Ricerche sulla seconda rivoluzione scientifica. Milan: Mondadori.

Blanke, Horst-Walter. 1983. "Verfassungen, die nicht rechtlich, aber wirklich wird: A.H.L. Heeren und das Ende der Aufklärungshistorie." Berichte zur Wissenschaftsgeschichte 6:143-64.

Bopp, Franz. 1820. "Analytical Comparison of the Sanskrit, Greek, Latin and Teutonic Languages." Annals of Oriental Literature 1:1-65.

Bouterwek, Friedrich. 1801-19. Geschichte der Poesie und Beredtsamkeit seit dem Ende des dreizehnten Jahrhunderts. 12 vols. Göttingen: Röwer.

Carhart, Michael. 2009. "Polynesia and Polygenism: The Scientific Uses of Travel Literature in the Early 19th Century," History of the Human Sciences 22, no. 2:58-86.

60. See Pim den Boer, History as a Profession: The Study of History in France, 1818-1914 (Princeton, NJ: Princeton University Press, 1998), chap. 5; Jo Tollebeek, Fredericq \& Zonen: Een antropologie van de moderne geschiedwetenschap (Amsterdam: Bert Bakker, 2008), chap. 2. 
Cohen, Floris. 1994. The Scientific Revolution: A Historiographical Inquiry. Chicago: University of Chicago Press.

Court de Gébelin, Antoine. 1773-82. Monde primitif analysé et comparé avec le monde moderne. 9 vols. Paris: Boudet et al.

Cunningham, Andrew, and Percy Williams. 1993. "De-centring the 'Big Picture': 'The Origins of Modern Science' and the Modern Origins of Science." British Journal for the History of Science 26, no. 4:407-32.

Daston, Lorraine, and Catherine Park. 2006. "Introduction: The Age of the New." In Early Modern Science, vol. 3 of The Cambridge History of Science, edited by Lorraine Daston and Catherine Park, 12-13. Cambridge: Cambridge University Press.

De Gérando, Joseph-Marie. 1804. Histoire comparée des systèmes de philosophie, relativement aux principes des connaissances humaines. 3 vols. Paris: Henrichs.

Den Boer, Pim. 1998. History as a Profession: The Study of History in France, 1818-1914. Princeton, NJ: Princeton University Press.

Destutt de Tracy, Antoine. 1798. “Mémoire sur la faculté de penser.” In Mémoires de l'Institut National des Sciences et des Arts pour l'An IV: Sciences morales et politiques, 1:283-450. Paris: Baudouin.

Du Ponceau, Peter Stephen. 1838. Mémoire sur le système grammatical des langues de quelques nations indiennes de l'Amérique du Nord. Paris: Pihan de la Forest.

Forster, Georg. 1777. A Voyage round the World. London: White et al.

1789. Review of Christoph Meiners, Grundriß der Geschichte der Menschheit. Allgemeine Litteratur-Zeitung, nos. 136-38 (May 4-6): 274-92.

Gervinus, Georg. 1837. Grundzüge der Historik. Leipzig: Engelmann.

Guillaume, James. 1891-1907. Procès-verbaux du Comité d'instruction publique de la Convention nationale. 6 vols. Paris: Imprimérie Nationale.

Hacking, Ian. 2002. “'Style’ for Historians and Philosophers.” In Historical Ontology, 178-99. Cambridge: Cambridge University Press.

Hahn, Roger. 1971. The Anatomy of a Scientific Institution: The Paris Academy of Sciences, 1666-1808. Berkeley: University of California Press.

Hegel, Georg Wilhelm Friedrich. 1844. Vorlesungen über die Geschichte der Philosophie, edited by Carl Michelet. 2nd ed. 3 vols. Berlin: Duncker \& Humblot.

Herder, Johann Gottfried von. 1827-28. Philosophie de l'histoire de l'humanité. Translated by Edgar Quinet. 2 vols. Paris: Levrault.

Hermann, Gottfried. 1819. Über das Wesen und die Behandlung der Mythologie: Ein Brief an Herrn Hofrath Creuzer. Leipzig: Fleischer.

Horne Tooke, John. 1840. Epea Pteroenta; or, The Diversions of Purley. London: Tegg.

Jardine, Nicholas. 1991. "Writing Off the Scientific Revolution." Journal of the History of Astronomy 22:311-18.

Kant, Immanuel. 1998. Critique of Pure Reason. Translated by Paul Guyer and Allen Wood. Cambridge: Cambridge University Press.

Lennep, Johan Daniel van. 1779. In analogiam linguæe Groece. Utrecht: Paddenburgh.

Meiners, Christoph. 1785. Grundriß der Geschichte der Menschheit. Göttingen: Röwer.

Michelet, Jules. 1831-33. Histoire romaine. 2 vols. Paris: Hachette.

- 1834. Introduction à l'histoire universelle. 2nd ed. Paris: Hachette.

-1871-74. Histoire de France. 17 vols. Paris: Librairie Internationale.

Müller, Karl Otfried. 1887. Handbuch der Archäologie der Kunst. 4th ed. Stuttgart: Heitz.

Niebuhr, Barthold. 1811-12. Römische Geschichte. 2 vols. Berlin: Realschulbuchhandlung. - 1813. Review of Arnold Heeren, Ideen über die Politik, den Verkehr und den Handel der vornehmsten Völker der Alten Welt, vol. 3. Ergänzungsblätter zur Jenaischen allgemeinen LiteraturZeitung 1, nos. 7-12:49-90. 
Nippel, Wilfred. 2013. "Barthold Georg Niebuhr: Ein schwieriger Gründervater." In Klio dichtet nicht: Studien zur Wissenschaftsgeschichte der Althistorie, 93-130. Frankfurt: Campus.

Orelli, Johann Caspar von. 1816. Review of Barthold Niebuhr, Römische Geschichte. Ergänzungsblätter zur Jenaischen allgemeinen Literatur-Zeitung 2, nos. 91-92:337-46.

Pott, August. 1833-36. Etymologische Forschungen auf dem Gebiete der Indo-Germanischen Sprachen. 2 vols. Lemgo: Meyer.

Ranke, Leopold von. 1824. Geschichten der romanischen und germanischen Völker von 1494 bis 1519. 2 vols. Leipzig \& Berlin: Reimer.

Robertson, John. 2005. The Case for the Enlightenment: Scotland and Naples, 1680-1760. Cambridge: Cambridge University Press.

Rorty, Richard. 1979. Philosophy and the Mirror of Nature. Princeton, NJ: Princeton University Press. Schlegel, August Wilhelm. 1827. "An der Professor Heeren in Göttingen: Über die Abtheilung von den Indern in seine Ideen über die Politik, den Verkehr und den Handel der vornehmsten Völker der alten Welt," Indische Bibliothek 2:373-473.

Schneider, Ulrich. 1990. Die Vergangenheit des Geistes: Eine Archäologie der Philosophiegeschichte. Frankfurt: Suhrkamp.

Solleveld, Floris. 2014a. "Conceptual Change in the History of the Humanities." Studium: Tijdschrift voor Wetenschaps- en Universiteitsgeschiedenis 7, no. 4: 223-39.

2014b. "What Books Are Made Of: Scholarship and Intertextuality in the History of the Humanities." In The Making of the Modern Humanities, vol. 3 of The Making of the Humanities, edited by Rens Bod, Jaap Maat, and Thijs Weststeijn, 265-79. Amsterdam: Amsterdam University Press.

Stewart, Dugald. 1829a. Dissertation exhibiting a General View of the Progress of Metaphysical, Ethical and Political Philosophy since the Revival of Letters. 2nd ed. Works 6. Cambridge: Hilliard \& Brown.

. 1829b. Elements of the Philosophy of the Human Mind. 3 vols. Works 3-5. Cambridge: Hilliard \& Brown.

Taine, Hyppolite. 1872. History of English Literature. Translated by Henri van Laun. 2nd ed. Edinburgh: Edmonston \& Douglas.

Thierry, Augustin. 1840. Considérations sur l'histoire de France. Paris: Garnier.

- 1866. Lettres sur l'histoire de France. 4th ed. Euvres 1. Paris: Garnier.

Tollebeek, Jo. 2008. Fredericq \& Zonen: Een antropologie van de moderne geschiedwetenschap. Amsterdam: Bert Bakker.

Vico, Giambattista. (1725) 2002. The First New Science. Translated by Leon Pompa. Cambridge: Cambridge University Press.

- (1744) 1948. The New Science of Giambattista Vico. Translated by Thomas Bergin and Max Fisch. Ithaca, NY: Cornell University Press.

1827. Principes de la Philosophie de l'Histoire. Translated by Jules Michelet. Paris: Renouard. . 1944. The Autobiography of Giambattista Vico. Translated by Max Fisch and Thomas Bergin. New York: Cornell University Press.

1999. New Science. Translated by David Marsh. London: Penguin.

Wachler, Ludwig. 1812-20. Geschichte der historischen Forschung und Kunst: Seit der Wiederherstellung derselben bis an das Ende des achtzehnten Jahrhunderts. 5 vols. Göttingen: Röwer.

Whiter, Walter. 1811-25. Etymologicon Universale, or Universal Etymological Dictionary. 3 vols. Cambridge: Cambridge University Press.

Wolf, Friedrich August. 1807. "Giambattista Vico über den Homer." Museum der AlterthumsWissenschaft 1:555-70. 